\section{ECONOMICS}

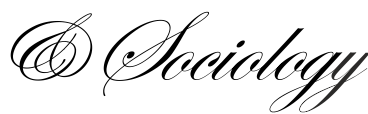

\title{
COMPARISON OF THE SELECTED INDICATORS OF WORK LIFE BALANCE IN EUROPEAN UNION COUNTRIES
}

\author{
Kristína Bulková, \\ Alexander Dubrék University of \\ Trenč̀n, \\ Trenčn, Slovakia, \\ E-mail: \\ kristina.bulkova@tnuni.sk \\ Tatiana Masárová, \\ Alexander Dubček University of \\ Trencín, \\ Trenčn, Slovakia, \\ E-mail: \\ tatiana.masarova@tmuni.sk
}

Received: July, 2016

1st Revision: October, 2016

Accepted: December, 2016

\begin{abstract}
The article elaborates on the characteristics and indicators of work life balance (WLB). The focus is on the selected criteria of WLB as well as social life and time spent off work. The WLB factors chosen and discussed are: the amount of stress, exhaustion and lack of time for family activities and responsibilities in the context of WLB. The results of the European survey conducted by the Eurofond are compared with the authors' questionnaire survey conducted in Slovakia in 2015. The survey results revealed stress and working hours to be statistically significant factors that can be seen as obstacles in the WLB and fulfilling family duties for many Slovaks. The survey also shows that the given sample of Slovak respondents performed much worse in the criteria of stress and lack of time results than the European average according to the Eurofond survey. The results could be partly influenced by the fact that the survey participants were mostly employed in the social sector.
\end{abstract}

DOI: $10.14254 / 2071-$

789X.2017/10-1/16

JEL Classification: I30, I31

Keywords: WLB, stress, exhaustion, time, family responsibilities, EU, Slovak respondents.

\section{Introduction}

The concept of balance of professional and personal life gained significant importance in the last two decades. This concept became in focus for governments as well as employers, labour unions and academia. In the context of academic literature it is an interdisciplinary problem researched in psychology, sociology, economics and management. Researches on this e topic aim to provide practical outcomes that would help preventing the negative impacts due to lack of work life balance of employees. Globally, the issue of work-life balance was first addressed by Canadian researchers in 2001 (Canadian policy research network, Ottawa). In addition, the United Nations Organization was also engaged in developing a job-quality set of indicators in 2010 (UN Economic commission for Europe, UNECE). In Europe, the following institutions dealt with work-life balance: Laeken indicators of job quality (2001), EUROFOUND (2002), Employment in Europe 2008, ETUI Proposal (2008, UNECE Proposal (2010), European Commission Proposal (2010), The Employment Committee, 
EMCO (2011). The Work Life Balance measurements by EMCO also provides statistical data. Visser, Williams (2007) suggested that work-life balance has become increasingly important for a number of social and economic reasons that are making organizations think about how they work, government think about how people balance paid and unpaid work and care while individuals think about the role work has and will have at different stages of their lives. WLB is defined differently and consensus is only reached on the definition for division of activities as work related and non-work related and the time allocation - balance between these two dimensions. Empirical research on this topic is initiated by the European Union in frequent intervals. European Foundation for the improvement of living and working condition along with the European working conditions survey and the European business survey (Giaccone, Cesos, 2010) aim to contribute to better living standards and working conditions. The WLB concept of successfully combining professional and personal life is part of European policies and priorities. The novelty and contribution of the study below lies in comparing WLB in the EU calculated as the average for the selected years of 2003, 2007, 2012 with the data obtained from authors' own questionare research on WLB in Slovakia.

\section{Literature review}

Academics haven't reached consensus on the understanding and definition of the WLB concept. Therefore one of the possible definitions or views of the concepts is the division of the activities into two categories: work related and non-work related life. Gröpel (2006, p. 72) defined it as the division between the different categories of work and non-work nature. Author states that the balance between work and non-work life is seen by individuals, when time is dedicated to both, However it is seen subjectively. Visser, Williams (2006) classify WLB in accordance with priorities of an individual and compatibility with the life fulfilment and work and life roles of this individual, meaning that WLB can be described as state where the devoted time for work and other activities reflects priorities, needs and ambitions of a person.

Poelsman. Caligiuri (2008) state that WLB is for the majority of population comprehended as temporary state of harmony or homeostasis, without mental pressure, where harmony can be seen as compatibility, satisfaction and subjective well-being. Balance can be described as equilibrium, state that can begin when two objects are in balance, equally distributed. Poelsman, Caligiuri (2008) claim that this definition is not fully reflected in the concept of WLB, given example that hardworking individual spending larger proportion of time at work, can be at balance, when and if the needs of the individual are fulfilled. Work and social life do not necessarily have to have the same time allocation, time spent in both is not needed to be equal and can still be at balance. Similarly, Kaiser et al. (2010) propose work-life balance interpretation as adaption to changing requirements and needs of all employees in line with the organization/company and not an equal time distribution.

Sojka's (2007, p. 94) perspective on WLB is taken from the standpoint of an employee, where WLB is achieved when none of the work life indicators impact negatively personal life of the employee. Negative impact is understood as lack of personal life or no desired disruptions to the personal life. Yuile et al. (2012) defines WLB as a state, where wide range of needs is being fulfilled by time division for the roles responding to both personal priorities and professional requirements. Clarke et al. (2004) confirms the different comprehensions and angles of understanding WLB concept, but authors conclude that mostly the WLB concept is contextually embedded with the balance of time invested and effort given, that an individual allocates between work and personal activities with the aim of life harmony.

This paper understands and comprehends WLB in these characteristics: 
1. Activities divided into two categories: work related, personal.

2. Time and effort balance between work and personal life.

3. Balance in context of person's priorities and needs.

4. Subjective interpretation of balance, in context of changing conditions.

5. Control and independence in professional life.

6. The goal of balance is subjective well-being of a person.

The use of WLB to provide and support the welfare of both the individuals and their families is expected to improve organizational outcomes by enabling company members to improve levels of job satisfaction and commitment to work (Navarro, 2016).

Work-life balance is subjective concept as for every person the meaning differs; therefore all recommendations suggested for employers should be seen in the context of these limitations. It is not possible to apply the same policies and changes in different organizations without required adaptations. When evaluating any WLB improvement measures, it is necessary to consider needs and wants of employees of the organization, strategy and organizational culture. Employers are given many instruments that can result in improved WLB (flexible working hours, working from home, shared office/open space, and improved integration of employees upon their return, consultancy, and legal aid).

The work-life balance initiatives could be designed by organizations with or without participation of their employees. The study shows that there are several organizations that do not involve their employees in the designing of work-life programs, the WLB drives in these organizations were initiated by the top management with the intention of employee retention. Organizations also believe that top management support is critical in rolling out WLB initiatives. It was found that, even for the WLB proposals that impacted at the lower or middle level managers "getting the buy-in and the support from the top management is a must even with small-scale initiatives on work-life balance which are proved to have good impact on the employee satisfaction and retention worldwide" (Parakandi, Behery, 2016).

In the present social development of Western countries, WLB has become a desired commodity. An individual might feel pressure to construct a biographical WLB as a status symbol. A desirable option to establish a balance turns into an obligation. As WLB is regarded as an individual status symbol, the responsibility for its achievement shifts from the organizations, which were formerly in charge of delivering appropriate conditions for the employees, to the individual, who becomes responsible for her or his own WLB. On the one hand this implies more freedom and self-determination; on the other hand the biographical work needed here brings further tasks and imposition, which have to be burdened onto a postmodern worker (Schilling, 2015).

It is necessary to categorize the phenomenon of WLB into a broader context, which can be classified as the work life quality. Work life quality is an important factor used for economical ratings and in the term work life quality is known to academic literature in different forms and synonyms such as - quality of work, workplace quality, job role quality. There can be seen as a small difference among these.

Work Life Balance (WLB) is measured through several factors. In the literature and online sources several interpretations of these indicators are applied. It is suggested that the growing amount of criteria for evaluation of WLB do not contribute to improved evaluation, rather has an opposite effect. The authors also question if it is possible to point out the WLB level of a country. When measuring WLB composition indicators with multiple parameters, that are represented in different ratios are applied (Masárová, Živčicová, 2012). WLB indicators can be described to be a combination of qualitative - quantitative characteristics of social and economic processes embedded in social development of an individual and the public perception. 
Measuring of WLB is complicated due to the nature of this category that is composed of several components. Various elements of the work life dimensions are measured by a group of indicators. The selection of indicators is impacted by the purpose of the study and the use of these indicators in previous studies. Selected indicators are implemented in comparison of chosen countries. The WLB evaluation is in both objective and subjective views.

The objective data collected from administrative sources such as: part time contracts based on family situation. Objective aspects of WLB are understood in the context of given society. The data collection is composed of data collected from institutions, agencies, governmental organizations. Subjective data is collected from surveys based on the employee satisfaction of part time employed workers, who work part time due to their family situation (Bednárik, 2010).

The appropriateness of work-life balance initiatives is determined by various variables such as nature and the demography of the workforce and the cultural and legal framework in the local and regional business environment. There are some specific arguments about some of the modes of work-life balance initiatives available for organizations to choose. In certain cases these initiatives support and go along with what is stated in the literature in the field, in some other cases modified or differing scenarios are observed (Parakandi, Behery, 2016).

The paper elaborates on labour force (stress, exhaustion, lack of time for family engagement). But according to Vojtovič (2013) the economic production of today is based on sophisticated and highly efficient technologies, which do not require a lot of labour force.

\section{Methodology and data}

The goal of this paper is to compare the average results of WLB selected factors in European and Slovak surveys. Slovak survey results were obtained from questionnaire conducted among Slovak respondents from January till May 2015. The European survey (e.g. Giaccone, 2010) results were conducted by the Eurofound Foundation and are available on the website www.eurofound.europa.eu.

Under this objective, we focused on:

1. The stress indicator within the WLB.

2. The rate of fatigue indicator within the WLB.

3. The rate of lack of time indicator to meet the family duties within the WLB.

Data in Slovakia have been gained by questionnaires, which according to Svec et al. (1998) is a suitable exploration and evaluation tool through which the attitudes and opinions of interviewed persons are being assessed on a specified topic. Questionnaire being worked out by contained 17 questions of which clarity was verified in pre-survey. Out of the items being necessary for our paper we have selected the ones, which reveal a subjective assessment of work-life balance indicators: stress, fatigue, family responsibilities. The exact version of questions was as follows:

- Are you under stress due to problems connected with the balance between work and personal life?

- Does work fatigue limit you to perform domestic duties?

- How often do you find it difficult to meet the family duties because of the time spent at work?

The responses were scaled and respondents were selected the following options based on their subjective assessment. The results were processed in absolute and relative abundance and then statistical analyses have been executed. The zero hypotheses on two sets division compliance has been tested by means of the Kolmogorov-Smirnov double choice test: namely the European Union set, where the indicators we obtained as the average of three surveys 
conducted in 2003, 2007 and 2012 being compared with our survey conducted in Slovakia in 2015. If the value of probability $\mathrm{p}$ was less than the significance level $\alpha$ then the tested hypothesis $\mathrm{H}_{0}$ is rejected in favour of the alternative hypothesis $\mathrm{H} 1, \mathrm{H} 2$ and $\mathrm{H} 3$. The structure of Slovak respondents was as follows: $61 \%$ of women and $39 \%$ of men. $18 \%$ of respondents were less than 30 years old, $51 \%$ from 30 till 50 years old and $31 \%$ were over 50 years old. Respondents were employed in social services. In the employers' organization there is a continuous working operation and they are working in 12-hour work shifts, what may put increased work demands on them. The method of selection was not representative. The survey sample was selected randomly.

In this paper three scientific hypotheses were set out based on the relevant literature analysis and research being carried out. We set out alternative hypothesis.

H1: It is assume that the distribution of individual work-life balance stressors identified in the EU will be significantly different from the distribution being found out in the Slovakia. There are statistically significant differences in the responses regarding the particular work-life balance stressors identified in the EU and Slovakia. Between the average of EU and Slovakia, there is a statistically significant difference in work-life balance indicators.

$\mathrm{H} 2$ : It is assumed that the frequency of work fatigue impact on meeting the family duties will be statistically significantly different between the average values being found out in the EU and in Slovakia. There are no statistically significant differences in the responses between the work fatigue frequency impact on domestic duties performance by the EU and Slovakian respondents.

H3: It is assumed that the working time impact frequency to meet the family responsibilities will be statistically significantly different between the average values being found out in the EU and Slovakia. There are statistically significant differences in the responses on the working time impact on the working duties fulfilment. There is a statistical significance in the rate of lack of time indicator on meeting the family duties within the EU and SR.

\section{Results}

By the first item authors wondered if there is demonstrated a significant difference between European and Slovak respondents in the area of maintaining the balance between work and personal life due to stress. Respondents had the opportunity to select the following indicators: at work, at home, or in both areas and also the indicator a little / no stress. The results are shown in the Table 1.

Table 1. The perception of stress as a result of an imbalance between work and personal life

\begin{tabular}{lcc}
\hline & EU survey $(\%)$ & Slovak survey $(\%)$ \\
\hline at work and at home & 14.83 & 31 \\
\hline either at work or at home & 39.23 & 48.2 \\
\hline a little / no stress & 45.9 & 20.8 \\
\hline Kolmogor-Smirnov Test & 0.002818093 & \\
\hline
\end{tabular}

Source: Own creation.

In our case we investigated the stress impact while doing work and personal duties between European and Slovak respondents. Since the value of probability $\mathrm{p}$ is less than the significance level $\alpha$ : p (0.00282) $<\alpha(0: 05)$, there is a statistically significant difference in 
favor of Slovak respondents. This is a negative trend, because the Slovak respondents group is significantly more likely aware of stress at work and at home environment. Conversely, less significant proportion of Slovakian respondents feel a little or no stress in comparison with the EU ones. As further we can see in Table 1, within the European survey, the majority of respondents indicate "a little or no stress" $(46 \%)$, followed by the option "at work or at home" $(39 \%)$ and "at work and at home" indicated by $15 \%$ of the EU respondents. Slovak respondents indicated the option "little / no stress" at the lowest rates of $21 \%$, the option to be under stress at home and at work $-31 \%$ of Slovak respondents and "either at work or at home" $-48 \%$ of respondents.

Due to better clarity the obtained data are indicated even in a graphic version.

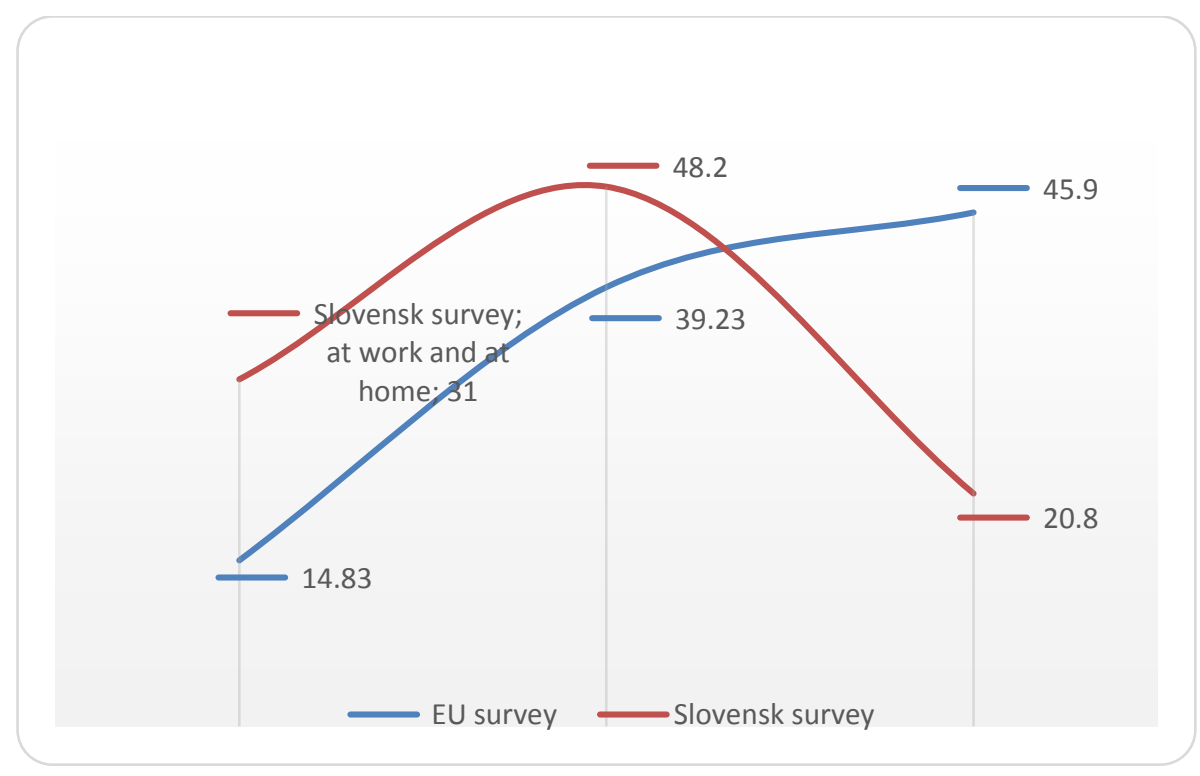

Figure 1. Results comparison of Work-life balance as a stressor

Source: Own creation.

The difference among respondents that was spotted in the stress indicator within the balance between work and personal life can be seen in Figure 1. The curves are most drifting apart in the third point. Statistically significant larger group of the EU respondents state that they are experiencing a little or no stress at work compared to respondents from Slovakian survey.

In the next component, the focus was on investigation of the impact of the work fatigue frequency to meet home duties. We were interested how European and Slovak respondents perceive the effect of work fatigue to meet their domestic duties (Table 2).

Table 2. Work fatigue as an obstacle to meet the duties at home

\begin{tabular}{lcc}
\hline & EU survey $(\%)$ & Slovak survey $(\%)$ \\
\hline Several times a week & 17.3 & 32.2 \\
\hline Several times a month & 31.13 & 28 \\
\hline Several times a year & 17.47 & 16.8 \\
\hline Less often / rarely & 22.3 & 16 \\
\hline Never & 9.83 & 7 \\
\hline Kolmogor- Smirnov Test & 0.241698548 & \\
\hline
\end{tabular}

Source: Own creation. 
The probability value $\mathrm{p}$ is bigger than the significance level $\alpha$ : $\mathrm{P}(0242)>\alpha(0: 05)$. No statistically significant difference between the Slovak and European respondents has been identified within the work fatigue frequency to meet the home duties. Table 2 also states that Europeans suffer from work fatigue resulting from meeting the home duties several times a week by $17 \%$, several times a month by $31 \%$, several times a year by $18 \%$, less often / rarely by $22 \%$, and never by $10 \%$. Slovak respondents feel work fatigue resulting from meeting the home duties several times a week by $32 \%$, several times a month by $28 \%$, several times a year by $17 \%$, less often / rarely by $16 \%$ and never by $7 \%$.

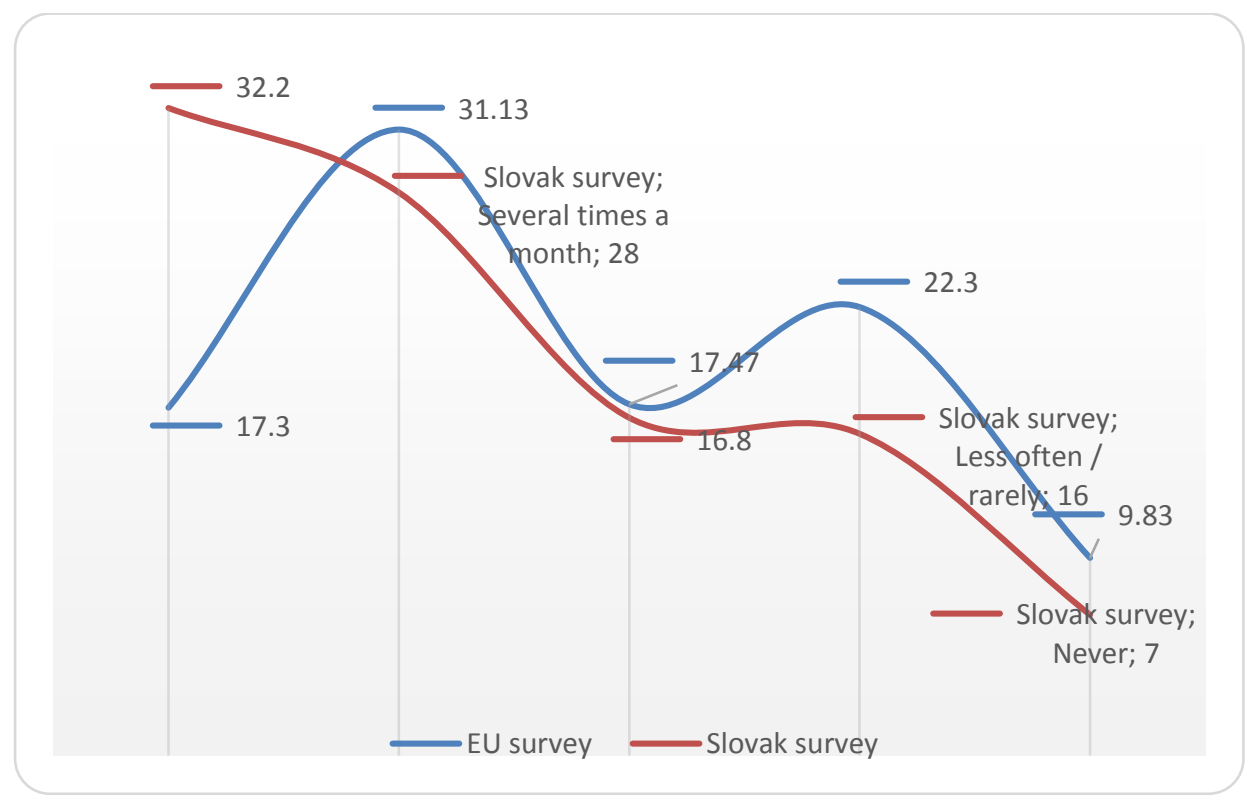

Figure 2. Results comparison of the fatigue work impact on meeting the home duties Source: Own creation.

Slovak respondents are experiencing work fatigue due to meeting the home duties almost twice as European respondents. The difference, identified by the graph curve in point 1 is not statistically significant. Therefore these differences must be regarded as accidental ones.

In the following part, authors were wondering whether respondents consider the time being spent at work as an obstacle to meet family duties. The Table 3 shows how European and Slovak respondents perceive the effect of working time to meet their family duties.

Table 3. Working time as a barrier to meet family duties

\begin{tabular}{lcc}
\hline & EU survey (\%) & Slovak survey (\%) \\
\hline Several times a week & 8.03 & 29 \\
\hline Several times a month & 26.7 & 24 \\
\hline Several times a year & 20.7 & 16.4 \\
\hline Less often / rarely & 27.5 & 18 \\
\hline Never & 17.1 & 12.6 \\
\hline Kolmogor-Smirnov Test & 0.019612311 & \\
\hline
\end{tabular}

Source: Own creation.

The probability value $p$ is smaller than the significance level $\alpha: p(0.01961)<\alpha(0: 05)$. Therefore we conclude that, a statistically significant difference between the Slovak and 
European respondents within the impact of working time frequency on meeting the family duties has been identified. There is a statistically significant difference in favour of Slovak respondents who said that the working hours appeared to be an obstacle for them to meet the family duties in the mode of several times a week. This is obviously a negative trend. Table no. 10 then states that the Slovak respondents are experiencing a work fatigue that results from home duties several times a week by $29 \%$, several times a month by $24 \%$, several times a year by $16 \%$, less often / rarely by $18 \%$ and never by $13 \%$. Europeans see working time as an obstacle to meet family duties several times a week by $8 \%$, several times a month by $27 \%$, several times a year by $21 \%$, less often / rarely by $27 \%$ and never by $17 \%$.

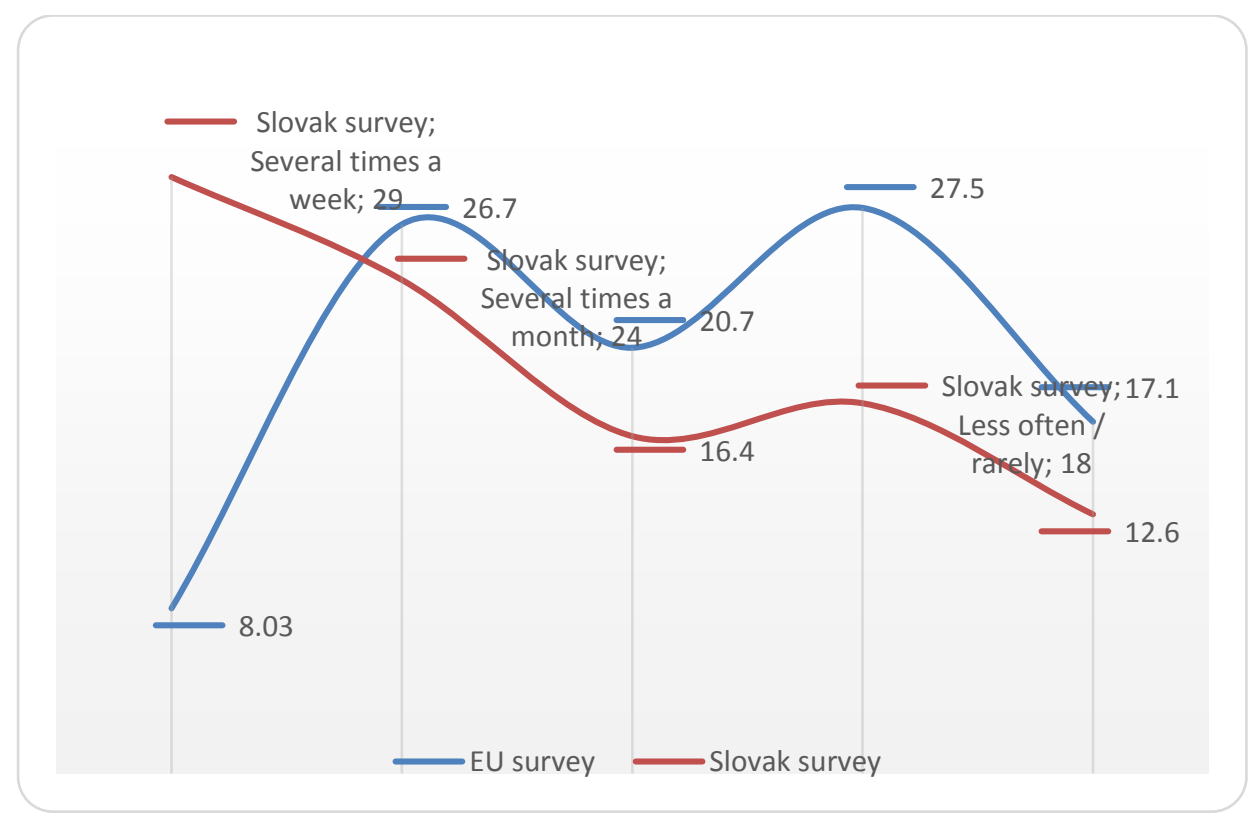

Figure 3. The results comparison of the work fatigue impact on meeting the family duties Source: Own creation.

The difference between respondents being seen within the factor of working time as an obstacle to meet the family duties is most distinctive in point 1. It states that Slovak respondents consider working time as an obstacle to meet family duties statistically more frequently (especially "several times a week") than European respondents. These differences were statistically supported and significance was demonstrated. Generally speaking, this implies that a statistically significantly larger group of Slovak respondents state that working time is an obstacle to meet family duties.

\section{Discussion}

The goal of this article is to compare the average results of WLB selected factors in European and Slovak surveys. The results show that Slovak respondents assess the impact of stress as significantly higher than European respondents. The group of Slovak respondents is significantly more likely aware of stress either at work or at home, compared with European respondents who indicated that the reconciliation of work and private life makes them a little or no stress. This fact could cause the fact that the Slovak respondents are working in social services, where there is an unrestricted operation. They work in 12 hour shifts, which can trigger an imbalance between work and personal life. The attempt to keep a balance seems to create stress that they are going through and is affecting them either at work or at home, or in both environments equally. 
Secondly, the interest of this research lied in whether the work fatigue appears to be an obstacle to meet the home duties. Slovak respondents most often replied that several times a week they are negatively affected by fatigue to meet family duties (32\%). European sample showed a response that several times a month Europeans feel negative effects of fatigue to meet family duties $(31 \%)$, however, a statistically significant difference has not been illustrated among the samples being surveyed. Even if Slovak respondents often feel tired from work, it has allegedly no effect to meet their home duties. It is believed that this finding might be accidental. However, stress may also be affected by personal characteristics (e.g. conscientiousness, selflessness, stability) and socially learned behaviour in educational pattern (e.g. responsibility for operation and maintenance of household, taking care of close family members) of Slovak respondents.

In the third indicator the focus was on the lack of time to meet the family duties. The results have shown that the Slovak respondents evaluates the working time as an obstacle to meet the family duties much more frequently than European respondents. The statistical significance in favour of Slovak respondents, in a negative sense, has also been showed because the time has been assessed as an obstacle to meet their family duties. Working time, which is an obstacle to meet the family duties has been reported by Slovak respondents in a frequency of several times a week $(29 \%)$ and European samples gave us as the most common answer "less often / rarely" (28\%). This trend may be primarily due to the fact that respondents who were interviewed they are working in continuous operation of 12 hour shifts and that can evoke in them a feeling of lack of time to meet the family duties. The time in this case is a measurable indicator and is more objective than a fatigue, which can be suppressed or restrained.

\section{Conclusion}

The outputs showed that in the measured variables (stress, fatigue and lack of time) Slovak respondents have achieved worse results than European sample, in two cases even significantly higher. It brought the questions of how working conditions are set for employees who evaluate indicators WLB as significantly lower, therefore relatively unsatisfactory. To be more objective as it comes to the interpretation of obtained data, the limitation that Slovak respondents were from the social services environment must be mentioned. Sample represented a specific group of employees, and therefore the results cannot be generalized. It is also one of the main limitations of this study. For the comparison to be more valuable it is appropriate to compare a balanced group of respondents, however there is a serious question, why the social services staff should not get closer to the EU average?

Employer plays a big role by reconciling working and non-working life. The employer is a major player with an impact on the institutional and structural aspects of support. The importance of support is not only the unilateral benefit for employees. Support also affects the employer, the country's economy and society. The employer can help employees to balance the work and family in ways such as: flexible working hours, by enabling shorter work load time, staff management training on work-life balance. It is suggested that organizations that respect the needs of their employees and apply WLB policies are perceived more positively, desirable and have a better reputation. The employees are more efficient and also more loyal, what leads the organization to achieve its prosperity and goals faster and more efficiently.

\section{References}

Bednárik, R. (2010), Kvalita pracovných miest, Bratislava: Inštitút pre výskum práce a rodiny. 
Clarke, H. D., Sanders, D., Stewart, M. C., Whiteley, P. (2004), Political Choice in Britain, Oxford: Oxford University Press.

Giaccone, M. (2010), Annual review of working conditions 2009-2010, Luxembourg: European union, available at: 2010http://www.eurofound.europa.eu/sites/default/files/ef_files/docs/ewco/tn1008048s/ tn1008048s.pdf.

Grőpel, P. (2006), Rovnováha životných oblastí vo vzt'ahu k naplnenosti potrieb a spokojnosti so životom, Československá psychologie, Vol. 50, pp. 71-83.

Kaiser, S., Ringlstetter, M. J.(2010), Work-Life Balance, Erfolgversprechende Konzepte und Instrumente für Extremjobber, Berlin: Springer Verlag.

Masárová, T., Živčicová, E. (2012), Meranie kvality života, Žilina: Georg.

Navarro, C., Gabriel, J., Vidal, S., Eugenia, M., Leiva, David, C. (2016), Linking Unlearning with Work-Life Balance: An Initial Empirical Investigation into SMEs, Journal of small business management, Vol. 54, Issue 1, pp. 373-391.

Parakandi, M. Behery, M. (2016), Sustainable human resources: Examining the status of organizational work-life balance practices in the United Arab Emirates, Renewable \& Sustainable Energy Reviews, Vol. 55, pp. 1370-1379.

Poelsman, S., Caligiuri, P. (2008), Harmonizing Work, Family and Personal Life. From Policy to Practice, Cambridge: Cambridge University Press.

Schilling, E. (2015), 'Success Is Satisfaction with What You Have'? Biographical Work-Life Balance of Older Female Employees in Public Administration, Gender Work and Organization, Vol. 22, Issue 5, pp. 474-494.

Sojka, L. (2007), Kvalita pracovného života a súvisiace konštrukt, Prešov: Prešovská univerzita.

Visser, F., Williams, L. (2006), Work-Life Balance: Rhetoric vs Reality, London: Work Foundation, available

at: http://www.theworkfoundation.com/DownloadPublication/Report/155_155_unison.pdf

Visser, F., Williams, L. (2007), Unison members and work-life balance. Forthcoming, London: Work Foundation.

Vojtovič, S. (2013), The impact of emigration on unemployment in Slovakia, Inzinerine Ekonomika-Engineering Economics, Vol. 24, No. 3, pp. 207-216.

Yuile, C., Chang, A., Gudmundsson, A., Sawang, S. (2012), The role of life friendly policies on employees' work-life balance, Journal of Management and Organization, Vol. 18, 1, pp. 53-63.

Zelina, M., Gavora, P., Kollárik, T., Lapitka, M., Švec, Š. et al. (1998), Metodológia vied o výchove, Bratislava: IRIS. 